\title{
シャント温存を目的としたシャント部動・静脈瘤形成術
}

\author{
早川邦弘 名嘉 栄勝 青柳 貞一郎宮地 系典 \\ 石川博通畠亮塩田潤*1 田中重 光*2 \\ 田中 新 樹*2 \\ 東京歯科大学市川総合病院泌尿器科 浦安市川市民病院*1 新友会本八幡腎クリニック*2
}

key words：内シャント, 動·静脈瘤, 手術成績

〈要旨〉

我々はすでに内シャント吻合部に発生した動・静脈瘤に対し，内シャントを温存する動・静脈瘤形成術を報告し た。今回，本術式を施行した症例の長期予後について検討した。

対象は 1995 年 7 月から 1999 年 8 月までの間に本術式を施行した 10 例である. 術式は内シャント動・静脈瘤の正 常血管構築を保っている部分を残し，仮性の瘤を形成している部分の壁を適切なサイズに形成した後に折りたたむ ように連続, 結節縫合で補強, 同部分のシャント血流を温存した。全例で予定通りの手術を施行することができた。 1 例は術後 7 か月で血管形成部に血栓による内シャント血流不全を生じ, 内シャントの再建を行った。しかし, 残り の 9 例は術後 25 か月の観察期間中，良好なシャント血流を維持することができた，観察期間中に瘤の再発，または 新たな部位の瘤形成をみた症例はなかった。

今回の結果から，本術式は長期においても内シャント温存の点から意義のある術式であると考えた。

\section{Clinical experience with method of our surgical repair for vascular access}

Kunihiro Hayakawa, Hidekatsu Naka, Teiichiro Aoyagi, Keisuke Miyaji, Hiromichi Ishikawa, Makoto Hata, Jun Shiota*1, Shigemitsu Tanaka*2, Araki Tanaka*2

Department of Urology, Ichikawa General Hospital, Tokyo Dental College : Department of Internal Medicine, Urayasu-Ichikawa Citizen's Hospital ${ }^{* 1}$; Motoyawata Kidney Clinic*2

We previously reported our method of surgical repair for pseudo-aneurysm developing at anastomosis site to preserve the original blood access. This study reports the long-term results of our procedure.

Between August 1995 through August 1999, 10 patients were included in this study. The procedures were as following; without touching the normal vascular structure at the aneurysm site, the redundant wall of the pseudo-aneurysm was repaired then re-sutured in a folding manner.

All cases were successfully completed. In one case, blood access was lost due to primary thrombosis at the site of plastic surgery 7 months postoperatively, but in the remaining 9 cases, access to the original blood flow was maintained in good condition during observation for 25 months. There was no recurrence or new aneurysm formation at different portion were seen during the observation period.

Based on the long-term results, we consider the method useful in terms of preserving the original blood access.

\section{緒言}

内シャントに発生する動・静脈瘤は大きなものでは 疼痛のみならず破裂の危険性もあり, しばしば外科的
治療の適応となる。しかしながら従来よく行われる 動・静脈瘤切除の術式では，シャントとしては良好な 機能を保っているにもかかわらず，瘤を切除するため に新たな動静脈吻合の再建を必要とする場合が多い。 このことは患者の長期展望を考えた場合, 貴重な自家

早川 邦弘 東京歯科大学市川総合病院泌尿器科干２72-8513 市川市菅野 5-11-13(0473-22-0151)

Kunihiro Hayakawa Fax. 0473-24-8587 


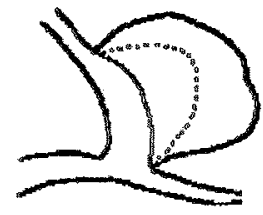

(4)

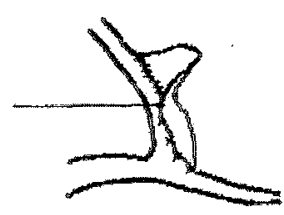

(2)

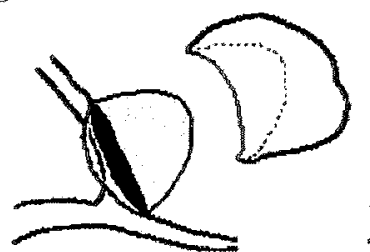

(5)

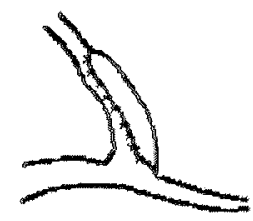

図 1 手術の手順(実線は手前の切開線, 破線は反対側の切開線). (1)動・静脈 瘤を全周にわたり剥離後，切開のデザインを決める。(2)動・静脈瘤壁の 余剩部分を切除する. (3)切開した壁の一側片を反対側の内腔に連続縫合 する。(4)切開壁の反対側を折りたたみかぶせるようにして巻き付け，同 様に結節縫合する。(5) 血流を再開し止血を確認する。

血管による内シャント作成可能部位を減らすことにな る。このため我々は内シャントの動静脈吻合部を温存 したままで動・静脈瘤修復を行う術式を開発し，すで に報告をしている泥、今回症例を重ね, 本術式により温 存された内シャントの予後と，術式の普遍化の可能性 について検討を加えたので報告する。

\section{I、対象および方法}

対象は 1995 年 7 月より 1999 年 8 月までの 4 年間に 当院および協力施設において加療した，内シャント動 静脈吻合部に発生した動・竫脈瘤 7 例と穿刺部に発生 した静脈瘤 3 例の計 10 例である. 男性 4 名女性 5 名で あり，女性のうち 1 名住吻合部動・静脈瘤と穿刺部に 発生した静脈瘤を合併して扝り，一期的に2 䈏所を治 療した。外科的治療を選択した理由は瘤の短期間での 急激な膨隆と緊満により破裂の危険性が考えられた症 例が 5 例，切迫破裂を起こして緊急入院となった症例 1 例, 疼痛が強く治療を希望した症例 2 例, 美容的な理 由によるもの 2 例であった。

手術方法は前回初例の報告時点では，折りたたむよ うにして周囲に巻き付けた二層目の血管壁の縫合も連 続縫合で行っていたが，5例目以降法二層目の縫合を 連続縫合から結節縫合に変更した。以下に簡単にその 方法を述べる。

1）内シャント吻合部に発生した動・静脈瘤，静脈 瘤に対し，流入血管，流出血管をすべて確保するのに 適切な切開線にて皮膚切開を施行後，注意深く瘤周囲 を剝離する。
2) 瘤を全周にわたり完全に剥離の後, す心゙ての流 入，流出血管に対し血管テープをかけてこれらを確保 する。

3）同部にてブルドック鉗子で止血の後，瘤をその 壁が一番菲薄になっている部分で血管の走行に沿い, 縦に切開する（図 1 (1)).

4) 瘤は多くの場合仮性血管瘤になっており，再建 後のデザインを考えた上で菲薄な壁の余唾部分を切除 し(図 1 (2))，再建後の血管内腔を確保するように切開 壁の一側辺を内腔に 7-0 血管吻合針で連続縫合する (図 1 (3))。その際，初め心数筫所結節縫合で壁を合わ せ，デザインしておくとよい。

5）切開壁の反対側を折りたたむようにして菲薄と なった血管瘤の壁周国に巻き付け，7-0血管吻合針で 結節縫合をする（図 1 (4))。

6 ）血流を再開し，止血を確認後閉創する。必要に 応じペンロースドレーンを留置する(図 1 (5))、ドレー ンは翌日には拢去する。術後 2 週間，塩酸于クロピジ ン $200 \mathrm{mg}$ の内服を行い, その後は減量のうえ約 1 か 月で中止した。

全症例について術前および術後 1 週間目, 術後 1 か 月目のシャント血流量を比較した。術後のシャント開 存日数，開存率は Kaplan-Meier の生存分析法にて評 洒した。

\section{III結 果}

全症例で予定通りの手術を完遂でき，術中に術式の 変更を余儀なくされた症例はなかった。瘤の長径，亦 
表 症例のプロフィール

\begin{tabular}{|c|c|c|c|c|}
\hline 症例 & 原病 & 瘤発生部位 & 術後経過 & その他 \\
\hline (1) 46 女 & 慢性腎炎 & 吻合部 & 19 か月後, 脳内出血にて死亡 & \\
\hline (2) 68 女 & 糖尿病性腎症 & 吻合部 & 5 加月後, 急性心筋梗塞にて死亡 & \\
\hline (3) 83 女 & 慢性腎炎 & 牚刺部 & 11 か月後, 誤飲にて死亡 & 切迫破裂にて緊急手術 \\
\hline (4) 62 男 & 慢性敏炎 & 穿刺部 & 血流良好にて 24 か月経過中 & \\
\hline (5) 58 女 & 慢性腎炎 & 吻合部 & 術後 7 か月で血流不全, 閉塞 & \\
\hline (6) 34 男 & IgA 腎症 & 吻合部 & 血流良好にて 15 汃月経過中 & \\
\hline (7) 76 男 & 慢性腎炎 & 吻合部 & 血流良好にて 8 办月経過中 & \\
\hline (8) 63 女 & 慢性腎炎 & $\begin{array}{l}\text { 吻合部 } \\
\text { 穿刺部 }\end{array}$ & 血流良好にて 7 か月経過中 & 一期的に手術 \\
\hline (9) 49 男 & 慢性腎炎 & 吻合部 & 血流良好飞て 8 办月経過中 & 瘤中枢側に狭窄を合併 \\
\hline
\end{tabular}

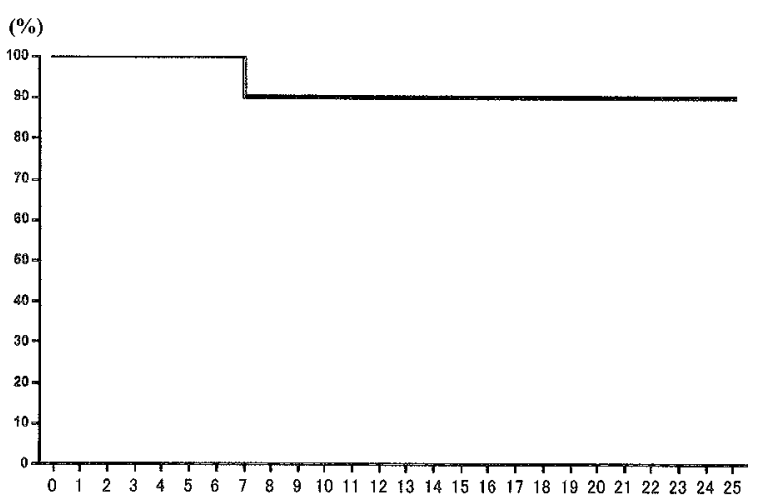

図 2 術後のシャント開存率. 術後 7 か月目で 1 例シャント不全により再手術を要した。6 か月開存率㹥 100\%，1 年開存率は $90 \%$ で ある。観察期間中に他因子死亡による脱落 症例が 3 例ある。

なわち血管形成に要した距離は $1.5 \sim 4.5 \mathrm{~cm}$ (平均 $3.8 \mathrm{~cm}$ ). 術中の所見では吻合部動・静脈瘤, 穿刺部静 脈瘤ともに全ての症例で瘤部の壁構造が菲薄化した仮 性血管瘤となっていた。術中の瘤の剝離の際, 1例で術 操作により溜の菲薄化した壁を損傷したが，初めに流 入，流出血管を確保していたため血流を遮断し，問題 なくその後の手術を続行し得た。1例で瘤の静脈流出 部に狭窄を認め, 同時に狭窄部の形成を行った。本症 例では瘤に加えた縦切開を狭窄部を超えた部分まで延 長し，狭窄部では内腔を広げるように縦切開部を横方 向に縫合した。瘤の部分は他の症例と同様に形成した。 ペンロースドレーンは全例翌日抜去し, 術後に再出血 や血腫形成を生じた例はなかった。全例で術直後から 内シャントの使用が可能であり，一時的透析カテーテ ルの留置を必要としなかった。術後 1 週間目には全例 で術前と同量の血流量を得ることができており，術後 1 か月目でも同様であった（表)。

現在までの観察期間は 8〜26 か月 (平均 14.7 か月). 観察期間中の死亡症例が 3 例あったが，いずれもシャ ントは開存していた。これらの死亡原因は脳出血，脑
炎，誤飲による窒息死であり，いずれも今回の動静脈 シャントの手術とは無関係であった。術後 7 か月目で シャント不全を起こし再手紨を要した症例が 1 例あ り, 術後の内シャント 6 か月開存率は $100 \%, 1$ 年以上 を経過した症例の開存率は $90 \%$ ある(図 2)。瘤の再 発, 手術部の感染症などの合併症を起こした症例はな かった。

\section{III. 考 察}

自家静脈内シャントに発生する動・静脈瘤の頻度は $0.8 \% ， 1.2 \%$ とするものから $28 \%$ とする報告まで様久 である ${ }^{2 \sim 6)}$ また，その部位により吻合部動・静脈瘤, 動脈化静脈瘤(部分的桩張), 動脈化静脈の全体的拡張, 穿刺部動・静脈瘤と分類できる ${ }^{4)}$ 。通常, 動・静脈瘤に 対し外科的手術が適応となる場合，溜切除のためシャ ント血流路の変更が必要となり, 動静脈の再吻合をす ることが多い7,8)。我々の方法は本来のシャント血流路 を温存できる点で試みるべき術式と考え，すでに吻合 部動・静脈瘤に適応した初例を報告した ${ }^{1)}$. その後適 応を広げ，吻合部動・静脈瘤のほか穿刺部動・静脈瘤 に対しても本術式を行った。

本術式の適応は菲薄化した壁を持つ仮性動・静脈瘤 であり，原則として中枢部に狭窄を伴わないものと考 えている。動脈化静脈瘤（部分的拡張）は，壁の全体 的肥厚と石死化の進行がみられることがあり, 菲薄化 して破裂の危険があると考えられる症例は少ないた め, 美容上の要望が強い場合を除いて原則として本術 式の適応からはずしている。また動脈化静脈の全体的 拡張に対しては，多くの症例で中枢に狭窄を伴ってお り，狭窄部の処置が優先すると考えている.

我々の症例では，1例に中枢側に狭窄部の合併を認 め一期的に処置した。シャント血管に一期的に複数䇢 所の処置をすることは術後の血流不全を起こしやすく すると考えられる。しかし瘤が発生するシャントは通 
常やや血流過多であり，他にも吻合部動・静脈瘤に第 刺部静脈瘤を合併した症例で一期的に 2 箇所の手術を 施行したが，いずれも術後の血流確保に問題はなかっ た.

術後 7 か月で血流不全によりシャントの再建を要し た 1 例は 60 歳女性に発生した吻合部動・静脈瘤の症 例である、溜の直径は $3.5 \mathrm{~cm}$ で狭窄などの合併はな かったが, 術後半年頃から血流不足が出現. 7 か月後に 血管形成部に血栓形成を生じ，閉塞したため内シャン 卜再建となった。この症例では閉塞部の組織学的検討 がなされなかったため審流不全の原因を特定すること は困難であったが，この症例以降の第 5 症例からは術 式に一部変更加光ることとした。すなわち第 4 症例 までは補強のため上からかぶせる血管壁の縫合も連続 縫合で行っていた。しかし二層目も連続縫合で water tightにすることにより，一層目と二層目の間に血液や 血漿などの貯留による解離，血腫形成，さらには内腔 の狭小化を引き起こす可能性があると考光，また手術 時間短縮の点加ら二層目以結節縫合で数箇所縫合する のみとした。術後の後出血もなく，形成した壁の耐圧 も含めて現在まで満足いく結果を得ている。

本術式は正常血管樍築を保っている部分を残し，仮 性の瘤を形成している部分の壁を折りたたむように補 強する形になっている。このため問題点として長期的 圧耐用性と形成血管の内腔確保があげられる。血管内 腔の確保は形成を要する血管長に影響を受ける。すな わち本術式の手術手技上のポイントは，内腔が充分に 確保されるように補強する壁のデザインを考える点に ある、このため，あまり瘤の長径が長いものでは血管 形成に困難を伴うが，我々の症例では最長 $4.5 \mathrm{~cm}$ ま で問題なく施行している。コツとして初めに約 $1 〜 1.5$ $\mathrm{cm}$ 間隔で数箇所に結節縫合をおき，一本の系で連続 縫合する距離をあまり長くしないことと考えている。 また我々の症例には含まれていないが，仮性動脈瘤が 全周にわたり形成されている例もあると考えられる。 このような場合は症例に応じた検討が必要ではある が，手術が適応となる例であれば瘤が正常血管の内腔 に比べ数倍になっており，二層目で全周をくまなく被 覆することにより血管壁が薄くなる部を残すことはな いと考えている。

現在までの結果で怯圧耐用性も内腔の確保による血 流の保持も長期的に問題がない。 また，瘤の再発や感 染の合併症もみられず，術後は通常のシャント静脈と
変わらない形態が維持されており，美容上の要望に対 しても十分に応えることができる結果である。今回の 検討から吻合部動・静脈瘤や穿刺部動・静脈瘤の上う な内シャントに発生した仮性血管瘤に対し，本法は長 期的にみても安定した成績を得ることができる術式で あることが確認できた。

\section{結語}

1）内シャント吻合部動・静脈瘤，穿刺部動・静脈 瘤に対し，内シャントを温存したままで血管溜修復を 行う術式を報告した。

2）術後 7 か月目に閉塞をした 1 例を除き，再発や 合併症はなく，長期的にも満足すべき開存率を示した。

3 ）本術式は透析患者にとり貴重な内シャントを温 存できる点から試みるべき術式と考光た

\section{文献}

1）早川邦弘, 西山 徹, 大橋正和, 石川博通, 畠亮： 内シャント吻合部動・静脈瘤修復の1術式，透析会誌 $29: 1409-1412,1996$

2) Haimov M, Baez A, Neff M, Slifkin R: Complications of arteriovenous fistulas for hemodialysis. Arch Surg 110: 708-712, 1975

3）酒井信治：外科的合併症とその処置, アクセスーブラッ ドアクセスとペリトネアルアクセス。臨牀透析 1： 177-185, 1985

4）沼田 明，今川章夫：晚期トラブル，動静脈瘤。ブラッ ドアクセストラブル (日本透析医研修委員会編), p 8589，金原出版，東京， 1991

5) Palder SB, Kirkman RL, Whitemore AD, Hakim RM, Lazarus JM, Tilney NL: Vascular access for hemodialysis. Patency rates and results of revision. Ann Surg 202:235-239, 1985

6) Zibari GB, Rohr MS, Landreneau MD, Bridges RM, DeVault GA, Pettty FH, Costley KJ, Brown ST, McDonald JC:Complications from permanent hemodialysis vascular access. Surgery 104:681686, 1988

7）暮原敬八郎，井上純雄，今并利一，中村成男：アクセ ストラブル一直接関係するもの，ブラッドアクセスイ ンターベンション治療の案際(阿岸鉄三, 天野 泉編), p 53-62，秀潤社，東京， 1999

8）合屋忠信, 福井博義, 武藤庸一：内シャント一晩期合 併症．ブラッドアクセス (合谷忠信編)，p 28-38，診断 と治療社，東索，1999 